\title{
Food and Nutrition Knowledge in Domestic Planning and Preparation of Meal in Oluwo Community, Obafemi Owode Lga, Ogun State, Nigeria
}

\author{
Akinsola, Olusola. O. \\ Department of Home Economics, Federal College of Education, Osiele, Abeokuta
}

\begin{abstract}
This study investigates the place of knowledge in food and nutrition in planning and preparing meals in the home within Oluwo community, Obafemi Owode Local Government Area, Ogun state. A random selection of one hundred (100) subjects from the community was selected. Data were obtained through the use of structured questionnaire and oral interview. The data were analyzed using simple percentages. The results of the findings showed that most people feed to keep alive rather than to keep fit. It was also revealed that some vital nutritional requirements were ignored during planning and preparation of meals due to lack of knowledge in food and nutrition and laissez-faire attitude that were displayed towards feeding pattern and health status. Based on these findings, corrective measures must be introduced, most especially during this economic recession plaguing the populace to educate individuals on the relevance of healthy diets, achieving optimal functioning of the body, re-engineering food and nutrition subjects right from the elementary classes through subsidized food practical by the school authorities, adopting aggressive campaign to remold peoples attitude towards improved healthy eating habits right from home, government should employ agricultural extension services and well-seasoned nutritionist to encourage rural household on how to develop healthy feeding habits.
\end{abstract}

\section{INTRODUCTION}

Over the years, the investigation of the role that food and nutrition played in preparation and planning meals at home has attracted the interest and concern of health practitioners, psychologists, researchers and health organizations in Nigeria. This is because of the public outcries concerning the poor nutritional status that is ravaging the country specifically during this economic recession presently being experienced in the country.

Though, from the earliest times, man has realized that providing for the family was one of his major tasks, as such, he knew food to be life sustaining and that satisfied stomach, bubbles forth happiness and contentment. Despite this fact, man still lack adequate knowledge in the significant relationship between food and nutrition and human health. Eze and Ibekwu, (2004) opined that the knowledge of food and nutrition in preparation and planning of meals cannot be overemphasized due to the fact that, the nutritional status of human body determine effective psychological behavior, emotional, social and health functioning.

Maureen, (2012) defined nutrition as the sum of all processes involved in how organisms obtain nutrients, metabolic and utilize same to support all life processes. She further buttressed the claim that without adequate nutrition the human body will not function optimally leading to severe nutritional inadequacy culminating into diseases even death. In the same vein, Meal-time memo, (2006) viewed nutrition as getting the calories needed for energy and the nutrients for proper growth, thoroughness, variety, balance, and moderation of food intake are the keys to achieving good nutrition.

From the foregoing, it is clearly revealed that nutrient could be viewed as a science that studies nutrients and other substances in foods and in the body, and the manner those nutrients relate to health and disease. Nutrients on the other hand are the nourishing substances in food which propel energy and promote the growth. Jomo, (2015) described nutrients as substances required by the body to perform its basic functions, these could be obtained from diet, to produce energy, detect and respond to environmental surroundings, move, excrete wastes, respire, grow and reproduce. The nutrients could be categorized into six classes namely: carbohydrates, lipids, proteins, water, vitamins, and minerals (Maureen, 2012). Nevertheless, malnutrition can be referred to as the insufficient, excessive or imbalanced consumption of nutrients (Christian, 2016). World Health Organization (WHO, 2016) 
Akinsola, Olusola. O.

in one of its report observed that malnutrition is by far largest contributor to child mortality. Globally, this condition during childhood usually results in worse health and lower educational achievements during adulthood.

\section{ObJECTIVES OF THE STUdY}

- To examine the pivotal roles knowledge in food and nutrition play in meals planning and preparation in the family.

- Determine the relationship between knowledge in food and nutrition and intellectual development of an individual.

- Investigate how knowledge in food and nutrition can assist family members to experience optimal body functioning.

\section{RESEARCH METHODOLOGY}

The population of this study was made up of 100 married women in Oluwo/Onikolobo Community in Obafemi Owode Local Government Area of Ogun State. Samples were randomly selected from the community. The instrument was personally administered by the researcher with the assistance of the screened enumerator which was validated by a research expert in the field to test for the reliability. The respondents were made to respond to the structured oral interview, while the literates among the respondents were given the structured questionnaire to fill in relation to the research work. The scores generated were subjected to simple percentage score.

\section{RESEARCH QUESTIONS}

1. What are the pivotal roles knowledge in food nutrition play in meal planning and preparation in the family?

2. Is there any relationship between knowledge in food and nutrition and intellectual development of an individual?

3. How can knowledge in food and nutrition assist family members to experience optimal body functioning?

\section{FINDINGS}

Research Question 1: What are the pivotal roles knowledge in food and nutrition play in meal planning and preparation for the family?

Table1. Family meals should be prepared to persevere nutrients contain in the diet.

\begin{tabular}{|l|l|l|}
\hline Options & Frequency (F) & Percentage \% \\
\hline Agreed & 62 & $62 \%$ \\
\hline Disagreed & 38 & $38 \%$ \\
\hline Total & $\mathbf{1 0 0}$ & $\mathbf{1 0 0}$ \\
\hline
\end{tabular}

Table2. In planning and preparation of meals, the age of the family members must be keenly considered.

\begin{tabular}{|l|l|l|}
\hline Options & Frequency (F) & Percentage \% \\
\hline Agreed & 30 & $30 \%$ \\
\hline Disagreed & 70 & $70 \%$ \\
\hline Total & $\mathbf{1 0 0}$ & $\mathbf{1 0 0}$ \\
\hline
\end{tabular}

Table3. Monotony of food should be avoided while planning and preparing food for the family.

\begin{tabular}{|l|l|l|}
\hline Options & Frequency $(\mathbf{F})$ & Percentage \% \\
\hline Agreed & 44 & $44 \%$ \\
\hline Disagreed & 56 & $56 \%$ \\
\hline Total & $\mathbf{1 0 0}$ & $\mathbf{1 0 0}$ \\
\hline
\end{tabular}

Research Question 2: Is there any relationship between knowledge in food and nutrition and intellectual development of an individual.

Table4. Balanced diet enhances individual's health.

\begin{tabular}{|l|l|l|}
\hline Options & Frequency (F) & Percentage \% \\
\hline Agreed & 58 & $58 \%$ \\
\hline Disagreed & 42 & $42 \%$ \\
\hline Total s & $\mathbf{1 0 0}$ & $\mathbf{1 0 0}$ \\
\hline
\end{tabular}


Food and Nutrition Knowledge in Domestic Planning and Preparation of Meal in Oluwo Community, Obafemi Owode Lga, Ogun State, Nigeria

Table5. Nourished meals improve intelligence of an individual.

\begin{tabular}{|l|l|l|}
\hline Options & Frequency (F) & Percentage \% \\
\hline Agreed & 41 & $41 \%$ \\
\hline Disagreed & 59 & $59 \%$ \\
\hline Total & $\mathbf{1 0 0}$ & $\mathbf{1 0 0}$ \\
\hline
\end{tabular}

Table6. Good feeding pattern promotes individual economic status.

\begin{tabular}{|l|l|l|}
\hline Options & Frequency $(\mathbf{F})$ & Percentage \% \\
\hline Agreed & 48 & $48 \%$ \\
\hline Disagreed & 52 & $52 \%$ \\
\hline Total & $\mathbf{1 0 0}$ & $\mathbf{1 0 0}$ \\
\hline
\end{tabular}

Research Question 3: How can knowledge in food and nutrition assist family members to experience optimal body functioning.

Table7. Nourishing meals repair worn out tissues in the body.

\begin{tabular}{|l|l|l|}
\hline Options & Frequency $(\mathbf{F})$ & Percentage \% \\
\hline Agreed & 41 & $41 \%$ \\
\hline Disagreed & 59 & $59 \%$ \\
\hline Total & $\mathbf{1 0 0}$ & $\mathbf{1 0 0}$ \\
\hline
\end{tabular}

Table8. Food in season should be incorporated into family menu.

\begin{tabular}{|l|l|l|}
\hline Options & Frequency (F) & Percentage \% \\
\hline Agreed & 77 & $77 \%$ \\
\hline Disagreed & 13 & $13 \%$ \\
\hline Total & $\mathbf{1 0 0}$ & $\mathbf{1 0 0}$ \\
\hline
\end{tabular}

Table9. Malnutrition sooner or later may result into severe disease even death.

\begin{tabular}{|l|l|l|}
\hline Options & Frequency $(\mathbf{F})$ & Percentage \% \\
\hline Agreed & 40 & $40 \%$ \\
\hline Disagreed & 60 & $60 \%$ \\
\hline Total & $\mathbf{1 0 0}$ & $\mathbf{1 0 0}$ \\
\hline
\end{tabular}

\section{DISCUSSION}

In table 1: $62 \%$ of the respondents agreed that family menu should be prepared with a method that preserves the food nutrients while 38\% disagreed. This result corroborates Tyagi et al, 2005 assertion that sometimes, in case of heating, macro nutrients such as carbohydrates, proteins, lipids, vitamins, and minerals are actually converted into harmful products, the overheating may alter the structure of nutrients thereby denaturing the food value.

In table 2: $30 \%$ of the respondents agreed to the fact that age of the family members must be considered when planning and preparing family meals, while $70 \%$ disagreed. The result of the respondents shows that there is need for food and nutrition knowledge for proper re-adjustment of family menu. This is in support of Yao et al 2001, that nutritional requirements change as individual gets older, even the growing children have different nutritional needs compared to adults since growing infant requires a higher intake of essential fatty acids than adults, moreover, individual level of activity will influence the nutritional requirement. Studies shows that receiving the right nutrient in the earliest of life is not only a matter of life and death, but a major determinant of future life chances (Jomo Kwame et al, 2015).

In table 3: $44 \%$ of the respondents agreed that monotony of food is wrong while, $56 \%$ disagreed that monotony should be avoided. The result support Maureen, 2012 report that a balanced diet include consuming more serving of nutrient-dense foods which can be achieved through varied diet to get necessary nutrients.

In table 4: $58 \%$ of the respondents agreed that balance diet enhances health status of an individual, while $42 \%$ disagreed. The result shows lack of nutritional knowledge. This result corroborates WHO, 2005 assertion that, lack of adequate information on the part of an individual may lead to malnutrition and not necessary lack of resources. 
In table 5: 41\% agreed that nourishing food improves human intelligence, while 59\% disagreed. The result shows that majority of the respondents fail to observe the tangible link between healthy diet and child's intelligence.

This support Ananya, 2017 assertion that children with malnutrition exhibit irritability and inability to concentrate.

In table 6: $48 \%$ of the respondents agreed that good feeding pattern promotes family economic status, while 52\% disagreed. The result is in support of Christian, 2016 who posited that poor diet may lead to a vitamin or mineral deficiency, this condition often times culminate to severe diseases and complications both in elderly and children as the adage has it that health is wealth.

In table 7: $41 \%$ of the respondents agreed that nourishing meals repair worn out tissues, $59 \%$ of the respondents disagreed. The result of the finding corroborates Ann, 2008 assertion that lack of information, economic insecurity and inadequate resources at all levels and unequal status of women may escalate malnutrition prevalence among family and community as well.

In table 8: $77 \%$ of respondents agreed that food in season should be included in family menu, while 33\% disagreed. The result of the findings is corroborated with Maureen, 2012 who posited that supplements contain only what is listed on the label. However, foods contain many more macronutrients, micronutrients and other chemicals, like antioxidants that benefits health. This assertion buttress the fact that wide array of nutrients can be consumed through food in season.

In table 9: $40 \%$ of the respondents agreed that malnutrition may sooner or later lead to severe sickness even death, while $60 \%$ disagreed. The result of the finding support Ann, 2008 who asserted that inadequate care of vulnerable household members such as "unfair" sharing of food within families could culminate to stunted growth, severe illness even death.

\section{CONClusion}

The result from the study has confirmed that every individual feed to keep alive rather than keep fit as it is reflected in the sample community of Oluwo. However, majority of these residents failed to perform the planning and cooking aspect of the meals aright. Though, the women strive to perform their motherly roles at the home front, yet some do this without any nutritional goals in mind, namely; giving careful consideration to the preservation of vital nutrients in meals during cooking, taking care of the vulnerable members in the family such as aged, children, and majorly, teens, exploring food in season in the family menu to avoid food monotony and feeding to build both the present and future health of the vulnerable members in the family.

The aforementioned findings revealed the huge gap in the knowledge of food and nutrition thereby necessitating urgent need on the part of the government, NGOs and renowned nutritionists in order to reduce the prevalence of malnutrition amongst family members since the condition of malnutrition is no respecter of family economic status. Triches; 2005 and Brow; 2004 opined that in order to promote healthy eating habits, nutrition knowledge is believed to be inevitable. Hence, nutrition knowledge alone may not be sufficient to achieve this, there may be need to adopt a positive attitude towards healthy eating habits early in childhood as the adage says that "charity begins from home".

\section{RECOMMENDATIONS}

Based on the result of the findings, the researcher tendered the following suggestions;

- Government and NGOs should mount up aggressive campaigns on good feeding habits amidst food scarcity, a timely one during this economic recession to gear up populace on the need to feed well irrespective of their economic status since malnutrition could be a condition of insufficient or excessive consumption of nutrients.

- Educationist should incorporate in school curriculum from elementary stage, the relevance of healthy diet through effective class session and subsidized food practical by the school authorities.

- Focus should be given to the usefulness of the local foods, fruits and vegetables rather than spending more on imported and processed foods.

- Government should employ agricultural extension services and well-seasoned nutritionists to disseminate information on healthy feeding habits to the rural communities.

- Sponsored adverts on how to adopt good feeding habits in various dialects should be tailored towards reaching people of varying backgrounds. 


\section{REFERENCES}

[1] Ananya Mandal, 2017: Neros medical life sciences.

[2] Ann Burgess (2008); Under nutrition in Adults and children: Causes, consequences and what we can do. South Sudan Medical Journal. www.southsudanmedicaljournal.com

[3] Brown R; (2004) Children's eating attitude and behavior; A study of the modeling and control theories of parental influence, Health Educ Res. Pubmed Christian Nordguist: 2016 www.medicalnewstoday.com

[4] Johnathon Andrew (Age related changes that affect Nutrition live healthy chronicles.com.

[5] Jomo Kwame Sundaram, Villcas Rawal, Micheal J. Clark (2015): ending malnutrition from commitment to achieve food \& agricultural organization of the united states.

[6] Maureen Zimmer mar \& Beth show (2012) An introduction to nutrition.

[7] Mealtime Moon for child care (2006).

[8] National food service management institute 200467: A nutrition curriculum guide for preschool children $\left(4^{\text {th }}\right.$ ed.) University of Mississippi.

[9] Triches R.M., Giugliani E.R.J; (2005) Obesity, Eating habits and nutritional knowledge among school children. Revsaude Publica.

[10] World health organization (WHO): Pocket of Hospital Care for Children: Guidelines for $h$ management of communities with limited resources: Geneva, 2005.

[11] Yao M, Robert SB, Ma G.S, Pan H, Mc Criry ma (2001). Field methods for body composition assessment.

\section{AUTHOR's BIOGRAPHY}

Akinsola, Olusola,O., is a seasoned lecturer who started her teaching career as an Assistant Lecturer in Home-Economics Department, Federal College of Education Osiele, Abeokuta, Ogun State almost two decades ago and has risen to the rank of Principal Lecturer. 